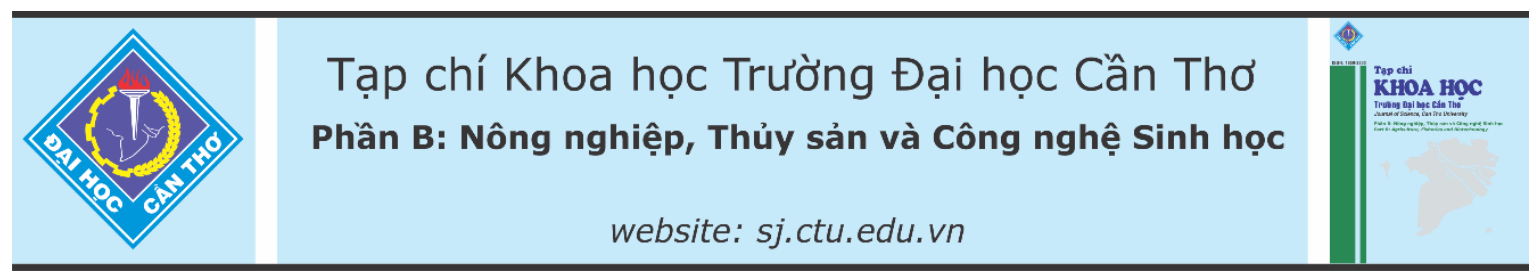

DOI:10.22144/ctu.jvn.2020.164

\title{
NGHIÊN CÚU Mọ̣T SỐ ĐIỀU KIỆN NUÔI TĂNG SINH VI KHUẨN Streptomyces SPP. TRONG PHÒNG THÍ NGHIỆM
}

\author{
Phạm Thị Tuyết Ngân*, Vũ Hùng Hải, Huỳnh Trường Giang và Vũ Ngọc Út \\ Bộ môn Thủy sinh họ ưng dụng, Khoa Thủy sản, Truờng Đại học Cần Tho \\ *Người chịu trách nhiệm về bài viết: Phạm Thị Tuyết Ngân (email: pttngan@ctu.edu.vn)
}

\section{Thông tin chung:}

Ngày nhận bài: 01/07/2020

Ngày nhận bài sủa: 24/09/2020

Ngày duyệt đăng: 28/12/2020

Title:

Optimization of in vitro culture conditions for production of Streptomyces spp.

\section{Tù khóa:}

Độ mặn, nguồn C và N, nhiệt đọ, $p H$, Streptomyces spp.

\section{Keywords:}

$C$ and $N$ sources, $p H$, salinity, Streptomyces spp., temperature

\begin{abstract}
The study was carried out to optimize in vitro culture conditions of increasing Streptomyces spp. growth rate. Physical and chemical conditions such as temperature, $\mathrm{pH}$, salinity, $C$ and $N$ sources were performed on 3 strains of Streptomyces spp. including TV1.4, CM2.4 and DH3.4 in m-ISP2 $C$ medium. After that, optimal $C$ and $N$ sources were selected to determine the optimal concentration for the growth of the studied bacterial strains. The experiments were designed in test tubes containing m-ISP2 medium with three replications. Bacterial growth was assessed by measuring optical density $600 \mathrm{~nm}$. The results showed that the optimal condition for TV1.4 strain grow best at $\mathrm{pH} 7$, temperature $30^{\circ} \mathrm{C}$, salinity $10 \%$, starch $2 \%$, tryptone $2 \%$. CM2.4 strain grow best at $\mathrm{pH} 8$, temperature $40^{\circ} \mathrm{C}$, salinity $10 \%$, starch $1 \%$, tryptone $1 \%$ and strain DH3.4 grow well at $\mathrm{pH} 7$, temperature $35^{\circ} \mathrm{C}$, salinity $10 \%$, starch $1 \%$ and tryptone at $2 \%$ concentration. Among the 3 studied strains, Streptomyces TV1.4 was the best selected bacteria strain.
\end{abstract}

\section{TÓM TÁT}

Đề tài được thực hiện với mục tiêu tối ưu các điều kiện nuôi tăng sinh để cải thiện tốc độ tăng truơong của các chủng Streptomyces spp. tiềm năng trong điều kiện in vitro. Các điều kiện nhiệt độ, $p H$, độ mặn, các nguồn $C$ và nguồn N được thực hiện trên 3 chủng vi khuẩn Streptomyces spp. TV1.4, CM2.4 và DH3.4 trong môi truờng m-ISP2 C. Sau đó, nguồn C và N phù hợp đươc chọn để xác định nồng độ tối ưu cho sự phát triển của các chủng vi khuẩn nghiên cứu. Thi nghiệm được bố trí trong ống nghiệm chứa môi truoờng m-ISP2 và mỗi nghiệm thức được lặp lại 3 lần. Tốc độ tăng truơơng của vi khuẩn được đánh giá thông qua giá trị hấp thu quang OD ở bước sóng $600 \mathrm{~nm}$. Kết quả cho thấy chủng TV1.4 phát triến tốt nhất ở pH 7 , nhiệt độ $30^{\circ} \mathrm{C}$, độ mặn $10 \%$, starch $2 \%$, tryptone $2 \%$. Chủng CM2.4 phát triển tốt nhất ở $\mathrm{pH} 8$, nhiệt độ $40^{\circ} \mathrm{C}$, độ mặn $10 \%$, starch $1 \%$, tryptone $1 \%$ và chủng DH3.4 phát triển tốt pH 7, nhiệt độ $35^{\circ} \mathrm{C}$, độ mặn $10 \%$, starch $1 \%$ và tryptone ở nồng độ $2 \%$. Trong 3 chủng nghiên cứu chủng Streptomyces TV1.4 là chủng vi khuẩn tốt nhất.

Trích dẫn: Phạm Thị Tuyết Ngân, Vũ Hùng Hải, Huỳnh Trường Giang và Vũ Ngọc Út, 2020. Nghiên cứu một số điều kiện nuôi tăng sinh vi khuẩn Streptomyces spp. trong phòng thí nghiệm. Tạp chí Khoa học Trường Đại học Cần Thơ. 56(6B): 246-253. 


\section{GIỚI THIỆU}

Việt Nam là một trong những quốc gia có nhiều tiềm năng về thủy sản, cả về lĩnh vực khai thác và nuôi trồng. Hiện nay, việc gia tăng mật độ nuôi để tăng sản lượng đáp ứng nhu cầu tiêu thụ, các mô hình nuôi thủy sản đã và đang gây nên những tác động xấu đến môi trường, dịch bệnh xảy ra thường xuyên và gây thiệt hại cho người nuôi. Bên cạnh các tác nhân nấm, ký sinh trùng, virus ... thì tác nhân vi khuẩn đã và đang gây thiệt hại lớn đến năng suất ở các mô hình nuôi tôm, cá. Một số bệnh điển hình do tác nhân là vi khuẩn gây ra như: bệnh hoại tử gan tụy cấp tính trên tôm do Vibrio parahaemolyticus (Lightner et al., 2013), bệnh gan thận mủ trên cá tra do Edwardsiella ictaluri (Crumlish et al., 2002).

Để hạn chế tình trạng ô nhiễm, cải thiện chất lượng nước và hạn chế dịch bệnh ngoài việc áp dụng các biện pháp xử lý cơ học, hóa học và thuốc kháng sinh thì biện pháp sinh học cũng đang được áp dụng ngày càng rộng rãi và mang lại nhiều hiệu quả (Verschuere et al. 2000; Balcazar et al., 2007; Mohkam et al., 2016). Việc nghiên cứu chọn lọc ra dòng vi sinh vật hữu ích tốt nhất ứng dụng cho nuôi trồng thủy sản mà không ảnh hưởng đến sức khỏe con người và đảm bảo chất lượng sản phẩm là một vấn đề cấp thiết. Một trong những đối tượng quan trọng nhất trong sản xuất các hợp chất có hoạt tính là xạ khuẩn vì đa số các cấu trúc có hoạt tính sinh học đều được tìm thấy ở xạ khuẩn (Sanglier et al., 1993). Streptomyces là một giống lớn nhất của ngành Actinobacteria (xạ khuẩn). Có hơn 500 loài vi khuẩn Streptomyces trong tổng số hơn 1.000 loài của xạ khuẩn đã được mô tả. Giống như hầu hết các xạ khuẩn khác, Streptomyces là vi khuẩn Gram dương, có bộ gene với tỉ lệ GC\% cao. Vi khuẩn này được tìm thấy chủ yếu trong đất và thảm thực vật mục nát. Streptomyces sinh bào tử, tạo mùi đặc trưng. Streptomyces được nghiên cứu rộng rãi và được biết đến nhiều nhất là giống của xạ khuẩn. Streptomyces thường sống ở đất có vai trò là vi sinh vật phân hủy rất quan trọng. Chủng vi sinh này sản xuất hơn một nửa số thuốc kháng sinh trên thế giới và đó là sản phẩm có giá trị lớn trong lĩnh vực y học. Streptomycetes cần nguồn carbon hữu cơ và muối khoáng, chúng không cần vitamin và các yếu tố tăng trưởng (Lee and Demain, 1997). Trong quá trình sống xạ khuẩn tiết ra nhiều chất có hoạt tính sinh học cao có khả năng kháng lại các loài vi sinh vật khác nhau bao gồm cả nấm và vi khuẩn (Robati and Mathivanan, 2013). Chủng vi sinh này sản xuất hơn một nửa số thuốc kháng sinh trên thế giới và đó là sản phẩm có giá trị lớn trong lĩnh vực y tế, do đó đề tài "Nghiên cứu một số điều kiện nuôi tăng sinh vi khuẩn Streptomyces spp. trong phòng thí nghiệm" được thực hiện với mục đích xác định điều kiện nuôi Streptomyces spp. thích hợp nhằm sản xuất chế phẩm vi sinh phục vụ nuôi trồng thủy sản.

\section{VẬT LIỆU VÀ PHƯƠNG PHÁP NGHIỀ CÚU}

\subsection{Thời gian và địa điểm nghiên cứu}

Nghiên cứu được thực hiện từ tháng 8 năm 2019 đến tháng 5 năm 2020 tại phòng thí nghiệm vi sinh vật hữu ích, bộ môn Thủy sinh học Ứng dụng, Khoa Thủy sản, Trường Đại học Cần Thơ.

\subsection{Vật liệu nghiên cứu}

Ba chủng xạ khuẩn thuộc Streptomyces sp. (TV1.4, CM2.4, DH3.4) có hoạt tính kháng vi khuẩn Vibrio parahaemolyticus tốt nhất trong bộ sưu tập vi khuẩn hữu ích tại phòng thí nghiệm Vi sinh vật hữu ích, Bộ môn Thủy sinh học Ửng dụng, Khoa Thủy sản, Trường Đại học Cần Thơ đã được chọn để tiến hành thí nghiệm.

\subsection{Phương pháp nghiên cứu}

\subsubsection{Phuơng pháp chuẩn bị sinh khối tế bào}

Các chủng xạ khuẩn được phục hồi trong môi trường $\mathrm{m}$-ISP2 (bổ sung $1 \% \mathrm{NaCl}$ ), ủ ở $37^{\circ} \mathrm{C}$ và lắc với vận tốc 150 vòng/phút. Sau 24 giờ nuôi, tiến hành ly tâm 4.000 vòng/phút trong 10 phút ở $4^{\circ} \mathrm{C}$ và rửa lại 2 lần với nước muối sinh lý $(0,85 \% \mathrm{NaCl})$ để thu sinh khối tế bào. Điều chỉnh mật độ tế bào bằng cách pha loãng dung dịch vi khuẩn từ $10^{8}$ còn $10^{6}$ CFU/mL bằng ống nghiệm chứa $9 \mathrm{~mL}$ nước muối sinh lý tiệt trùng sau đó xác định giá trị $\mathrm{OD}_{600}$ để phục vụ cho các thí nghiệm sau.

\section{muối \\ 2.3.2 Anh hưởng của nhiệt độ, $p H$ và nồng độ}

Mục đích của thí nghiệm nhằm đánh giá ảnh hưởng của nhiệt độ, $\mathrm{pH}$ và nồng độ muối $(\mathrm{NaCl})$ lên sự sinh trưởng của các chủng xạ khuẩn. Thí nghiệm được thực hiện dựa theo phương pháp Akond et al. (2016).

Ảnh hưởng của nhiệt độ: Dùng micropipette hút $0,1 \mathrm{~mL}$ sinh khối tế bào vi khuẩn ở mật độ $10^{6}$ $\mathrm{CFU} / \mathrm{mL}$ vào ống nghiệm chứa môi trường $\mathrm{m}$-ISP2 tiệt trùng. Xác định giá trị OD ban đầu của các ống nghiệm ở bước sóng $600 \mathrm{~nm}$ (do lượng vi khuẩn bổ sung cấy truyền đã được pha loãng và xác định ngay sau khi bổ sung nên không có sự khác biệt, thí nghiệm cũng được thực hiện lặp lại 3 lần). Các ống nghiệm được ủ ở các mốc nhiệt độ khác nhau $\left(20^{\circ} \mathrm{C}\right.$, $25^{\circ} \mathrm{C}, 30^{\circ} \mathrm{C}, 35^{\circ} \mathrm{C}, 40^{\circ} \mathrm{C}, 45^{\circ} \mathrm{C}$ và $50^{\circ} \mathrm{C}$ ) trên máy 
lắc. Sau 24 giờ, xác định giá trị $\mathrm{OD}_{600}$ ở các nghiệm thức để đánh giá sự sinh trưởng của 3 chủng vi khuẩn.

Ảnh hưởng của pH: Môi trường m-ISP2 được sử dụng để xác định ảnh hưởng của $\mathrm{pH}$ lên quá trình sinh trưởng của các chủng xạ khuẩn phân lập bằng dung dịch $\mathrm{HCl} 1 \mathrm{M}$ và $\mathrm{NaOH} 1 \mathrm{M}$ các nghiệm thức được bố trí ở các giá trị $\mathrm{pH}$ lần lượt là $4,5,6,7,8$, 9,10 và 11, mỗi nghiệm thức được lặp lại ba lần. Dùng micropipette bơm chuyền $0,1 \mathrm{~mL}$ sinh khối tế bào đã chuẩn bị trước đó vào ống nghiệm chứa môi trường $\mathrm{m}$-ISP2 tiệt trùng và ghi nhận giá trị $\mathrm{OD}_{600}$ ban đầu. Sau đó các nghiệm thức được nuôi trên máy lắc và xác định giá trị $\mathrm{OD}_{600}$ sau 24 giờ để đánh giá sự tăng trưởng của chủng vi khuẩn.

Ảnh hưởng của nồng độ muối NaCl: Các ống nghiệm chứa môi trường $\mathrm{m}$-ISP2 tiệt trùng được điều chỉnh ở các nồng độ muối $0 \%, 1 \%, 2 \%, 3 \%$, $4 \%, 5 \% \mathrm{NaCl}$, mỗi nghiệm thức được lặp lại ba lần. Sau khi dùng micropipette chuyển $0,1 \mathrm{~mL}$ sinh khối tế bào vào các ống nghiệm, giá trị $\mathrm{OD}_{600}$ vào thời điểm ban đầu và sau khi nuôi trên máy lắc trong 24 giờ ở nhiệt độ phòng đã được đo để xác định khả năng sinh trưởng của các chủng xạ khuẩn trong ống nghiệm.

2.3.3 Anh hưởng của việc bổ sung các nguồn carbon $(C)$ và nito $(N)$ lên sụ sinh truởng

Thí nghiệm được thực hiện dựa theo phương pháp Kiranmayi et al. (2011) với một vài thay đổi như sau:

Ảnh hưởng của các nguồn $\mathrm{C}$ : Các nguồn $\mathrm{C}$ khác nhau như maltose, sucrose, glucose, starch, glycerol được bổ sung riêng biệt vào môi trường mISP2 với liều lượng $1 \%$ (dựa vào báo cáo trước đây của Kiranmayi et al., 2011). Sau đó dùng micropipette hút $0,1 \mathrm{~mL}$ sinh khối tế bào vi khuẩn $\left(10^{6} \mathrm{CFU} / \mathrm{mL}\right)$ vào các nghiệm thức. Sau 24 giờ, mật độ tế bào được đo ở giá trị $\mathrm{OD}_{600}$ và chọn ra nguồn carbon tốt nhất để đánh giá ảnh hưởng các nồng độ khác nhau $(0,5 \%, 1 \%, 2 \%, 3 \%, 4 \%, 5 \%)$ lên sinh trưởng của vi khuẩn.

Ảnh hưởng của các nguồn $\mathrm{N}$ : Các nguồn $\mathrm{N}$ khác nhau (potassium nitrate, ammonium sulfate, peptone, tryptone, casein) bổ sung vào môi trường

ISP2 với tỉ lệ $0,5 \%$ (dựa vào báo cáo trước đây của Kiranmayi et al., 2011). Tiến hành tương tự như phương pháp trên, sau 24 giờ mật độ tế bào được đo ở giá trị $\mathrm{OD}_{600}$ và chọn ra nguồn $\mathrm{N}$ tối ưu để đánh giá ảnh hưởng các nồng độ $\mathrm{N}$ khác nhau $(0,1 \%$;
$0,25 \% ; 0,5 \% ; 1 \% ; 1,5 \% ; 2 \%)$ trong quy mô phòng thí nghiệm.

\subsection{Phương pháp xử lý số liệu}

Số liệu được thống kê và xử lý bằng phần mềm SPSS 16.0 và phần mềm Microsoft Excel 2013. Sự khác biệt có ý nghĩa giữa các nghiệm thức được kiểm tra bằng phép thử HSD ở mức ý nghĩa $p<0,05$.

\section{KẾT QUẢ VÀ THẢO LUẬN}

\section{1 Ảnh hưởng của các điều kiện nuôi cấy lên sự tăng trưởng của vi khuẩn Streptomyces chủng TV1.4, CM2.4 và DH3.4}

\subsubsection{Anh hương của $p H$}

Qua quá trình theo dõi, cả 3 chủng Streptomyces sp. nghiên cứu có khả năng phát triển trong khoảng $\mathrm{pH}$ từ 4-11, trong đó giá trị $\mathrm{OD}$ của chủng TV1.4 đạt cao nhất ở $\mathrm{pH}$ là 7 ứng với giá trị $\mathrm{OD}_{600}=1,135$ vào thời điểm thu mẫu lúc 24 giờ cao hơn và khác biệt có ý nghĩa thống kê $(p<0,05)$ so với các nghiệm thức còn lại (Hình 1a). Đối với chủng CM2.4 dao động OD trong khoảng từ 0,995 đến 1,049 có khoảng $\mathrm{pH}$ sinh trưởng tốt từ 7 đến 9 kết quả ghi nhận được ở $\mathrm{pH}=8$ có tốc độ tăng trưởng cao nhất với $\mathrm{OD}_{600}=1,064$, khác biệt không có ý nghĩa thống kê so với nghiệm thức ở $\mathrm{pH} 7$ và $9(p>0,05)$ nhưng lại cao hơn và khác biệt có ý nghĩa thống kê so với các nghiệm thức còn lại $(p<0,05)$ (Hình $1 b)$. Tương tự với 2 chủng trên, chủng $\mathrm{DH} 3.4$ có tốc độ tăng trưởng dao động trong khoảng từ 0,827 đến 0,860 có khoảng $\mathrm{pH}$ sinh trưởng tốt từ 7-8. Kết quả ghi nhận được ở $\mathrm{pH}$ là 7 có tốc độ tăng trưởng cao nhất với $\mathrm{OD}_{600}=0,860$, khác biệt không có ý nghĩa thống kê so với nghiệm thức ở $\mathrm{pH}$ là $8(p>0,05)$ nhưng lại cao hơn và khác biệt có ý nghĩa thống kê $(p<0,05)$ so với các nghiệm thức còn lại (Hình 1c).

Trong quá trình thí nghiệm khoảng $\mathrm{pH}$ tối ưu của 3 chủng vi khuẩn không có sự khác biệt đáng kể, thích hợp với môi trường trung tính hoặc hơi kiềm có $\mathrm{pH}$ trong khoảng từ 7 đến 8 . Kết quả trong nghiên cứu này tương tự với nghiên cứu trước đây của Cabell et al. (2003), vi khuẩn Streptomyces vẫn duy trì sự phát triển ở $\mathrm{pH} 6,5-8,0$. Chủng $\mathrm{DH} 3.4$ có tốc độ tăng trưởng thấp đáng kể so với 2 chủng vi khuẩn còn lại có thể do môi trường m-ISP2 dùng để nuôi vi khuẩn không phù hợp với chủng $\mathrm{DH} 3.4$ vì theo nghiên cứu của Mitra et al. (2008), xạ khuẩn thuộc nhóm sinh vật dị dưỡng, chúng sử dụng đường, rượu, acid hữu cơ, lipid, protein và một số hợp chất hữu cơ khác để làm nguồn $\mathrm{C}$; sử dụng muối nitrate, urea, amino acid, peptone để làm nguồn $\mathrm{N}$. Khả năng hấp thụ các chất này không giống nhau ở các loài, các chủng xạ khuẩn. 


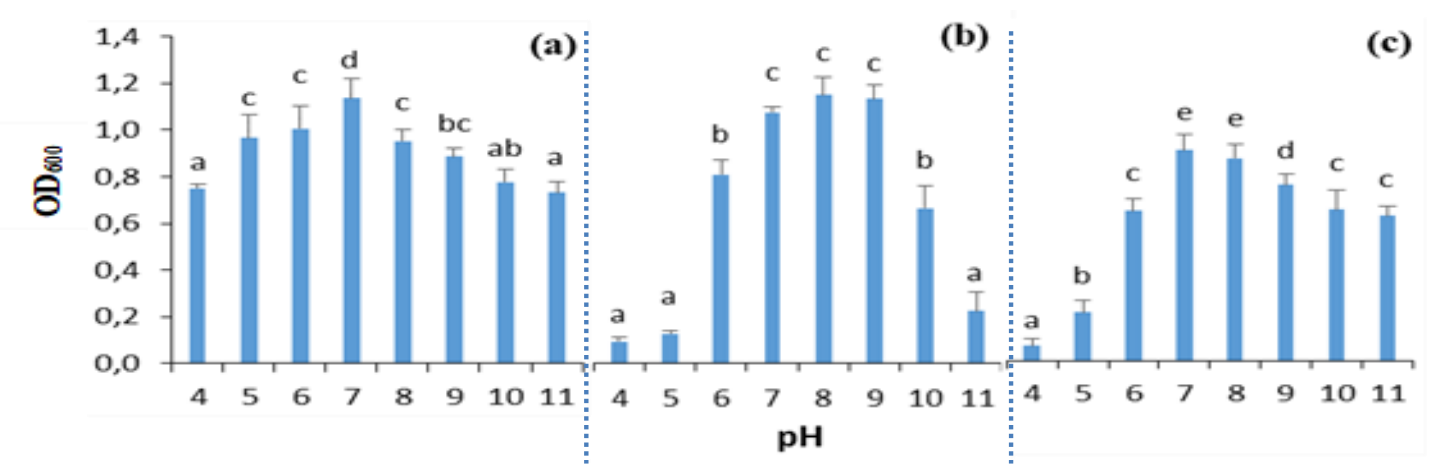

Hình 1: Ảnh hưởng của pH lên tăng trưởng của các chủng vi khuẩn

(a) TV1.4, (b) CM2.4 và (c) DH3.4

Các giá trị trung bình có các ký tụ mũ a, b, c khác nhau thì khác biệt có ý nghĩa thống kê ( $p<0,05)$.

\subsubsection{Anh huởng của nhiệt độ}

Kết quả cho thấy xạ khuẩn có thể phát triển ở nhiệt độ từ $15-50^{\circ} \mathrm{C}$. Tuy nhiên nhiệt độ thích hợp cho sự phát triển của chúng khoảng từ $30-40^{\circ} \mathrm{C}$ tùy theo loài. Trong 3 chủng nghiên cứu, chủng vi khuẩn TV1.4 có mật độ cao nhất khi nuôi tăng sinh ở $30^{\circ} \mathrm{C}$ $\left(\mathrm{OD}_{600}=0,784\right)$, nhưng khác biệt không có ý nghĩa thống kê so với nghiệm thức ở nhiệt độ $35^{\circ} \mathrm{C}$ $(p>0,05)$ nhưng lại cao hơn và khác biệt có ý nghĩa thống kê so với các mức nhiệt độ khảo sát còn lại $(p<0,05)$ (Hình 2a). Bên cạnh đó chủng vi khuẩn CM2.4 có tốc độ tăng trưởng cao nhất khi nuôi tăng sinh ở nhiệt độ $40^{\circ} \mathrm{C}$ với giá trị $\mathrm{OD}_{600}=1,038$ cao hơn và khác biệt có ý nghĩa thống kê so với các nghiệm thức nhiệt độ còn lại $(p<0,05)$ (Hình $2 b$ ). Tương tự, chủng vi khuẩn DH3.4 cũng có tốc độ tăng trưởng cao nhất khi nuôi ở nhiệt độ $35^{\circ} \mathrm{C}$ đạt giá trị $\mathrm{OD}_{600}=0,974$ không khác biệt có ý nghĩa thống kê so với 2 nghiệm thức ở nhiệt độ $30^{\circ} \mathrm{C}$ và $40^{\circ} \mathrm{C}(p>0,05)$ nhưng lại cao hơn và khác biệt có ý nghĩa thống kê so với các nghiệm thức nhiệt độ còn lại $(p<0,05)$ (Hình $2 c)$. Các nghiên cứu trước đây nhận định rằng hầu hết Streptomyces sp. phát triển tốt ở khoảng nhiệt độ $28-37^{\circ} \mathrm{C}$ (James et al., 1989; Deeble et al., 2005). Do vậy nghiên cứu này phù hợp với các nghiên cứu trước đây. Trong khi đó Srivibool et al. (2004) đã nghiên cứu ba loài Streptomyces thermonitrificans, S. thermovulgaris và $S$. thermoflavus cho thấy vi khuẩn tăng trưởng đạt sinh khối cao ở nhiệt độ nuôi cấy từ $40-45^{\circ} \mathrm{C}$. Một nghiên cứu khác cũng xác định xạ khuẩn Streptomyces parvulus HNR3X4 sinh trưởng tốt trên nhiều loại môi trường nuôi cấy với nhiệt độ phát triển từ $15-45^{\circ} \mathrm{C}$ và $\mathrm{pH}$ từ $4-9$ (Phan Thị Hồng Thảo và ctv., 2016).

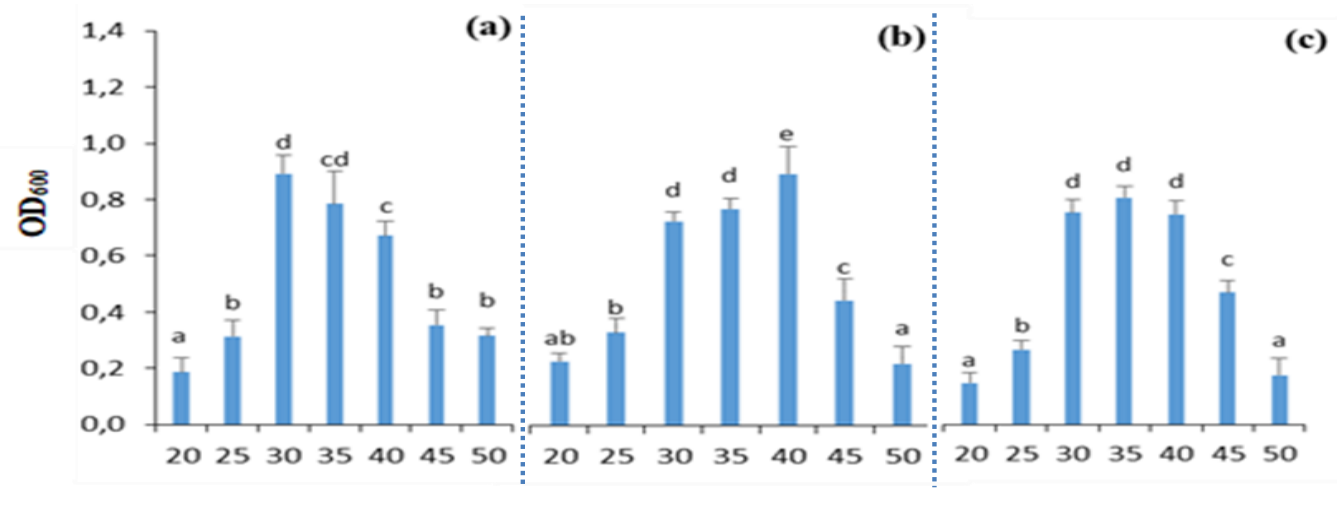

Nhiệt độ $\left({ }^{\circ} \mathrm{C}\right)$

\section{Hình 2: Ảnh hưởng của nhiệt độ lên tăng trưởng của các chủng vi khuẩn (a) TV1.4, (b) CM2.4 và (c) DH3.4}

Các giá trị trung bình có các ký tụ mũ a, b, c khác nhau thì khác biệt có ý nghĩa thống kê ( $p<0,05)$. 


\subsubsection{Anh hưởng của nồng độ muối (NaCL)}

Sau 24 giờ nuôi cấy, chủng TV1.4 có giá trị $\mathrm{OD}_{600}$ dao động từ 0,804 đến 0,870 . Trong đó, nghiệm thức có nồng độ muối $1 \%$ có tốc độ tăng trưởng cao nhất với giá trị $\mathrm{OD}_{600}=0,870$ không có ý nghĩa so với nghiệm thức $0 \%$ ở cùng thời điểm ( $p>0,05)$ nhưng lại cao hơn và khác biệt có ý nghĩa thống kê so với các nghiệm thức nồng độ muối còn lại (Hình 3a). Tương tự với chủng TV1.4, chủng CM2.4 cũng có tốc độ tăng trưởng cao nhất ở nghiệm thức có nồng độ muối $1 \%$ với giá trị $\mathrm{OD}_{600}$ $=1,128$ cao hơn và khác biệt có ý nghĩa $(p<0,05)$ so với các nghiệm thức nồng độ muối còn lại (Hình 3b). Chủng DH3.4 đạt giá trị OD dao động từ 1,212 đến 1,235 trong đó giá trị cao nhất ở nghiệm thức có nồng độ muối $1 \%$ với giá trị $\mathrm{OD}_{600}=1,235$, khác biệt không có ý nghĩa thống kê so với nghiệm thức có độ muối $2 \%(p>0,05)$ nhưng lại cao hơn và khác biệt có ý nghĩa thống kê so với các nghiệm thức độ muối còn lại (Hình 3c). Trong thí nghiệm cả 3 chủng đều sinh trưởng tốt ở nồng độ muối $1 \%$. Theo Larsen (1986), vi sinh vật chịu mặn có thể nhóm thành các nhóm theo nhu cầu về muối của chúng, các sinh vật chịu nồng độ muối thấp có thể sinh trưởng trong mồi trường nước biển với nồng độ muối từ 20-30\%o. Các chủng xạ khuẩn thuộc nghiên cứu này chịu nồng độ muối khoảng $0-10 \%$ nên có thể xếp vào nhóm chịu muối thấp. Kết quả này phù hợp với kết quả nghiên cứu đã công bố của Nguyễn Thị Minh Hằng và Đỗ Văn Bút (2013) khi cho rằng các chủng xạ khuẩn có thể sinh trưởng tốt ở độ mặn 0-20\%o.

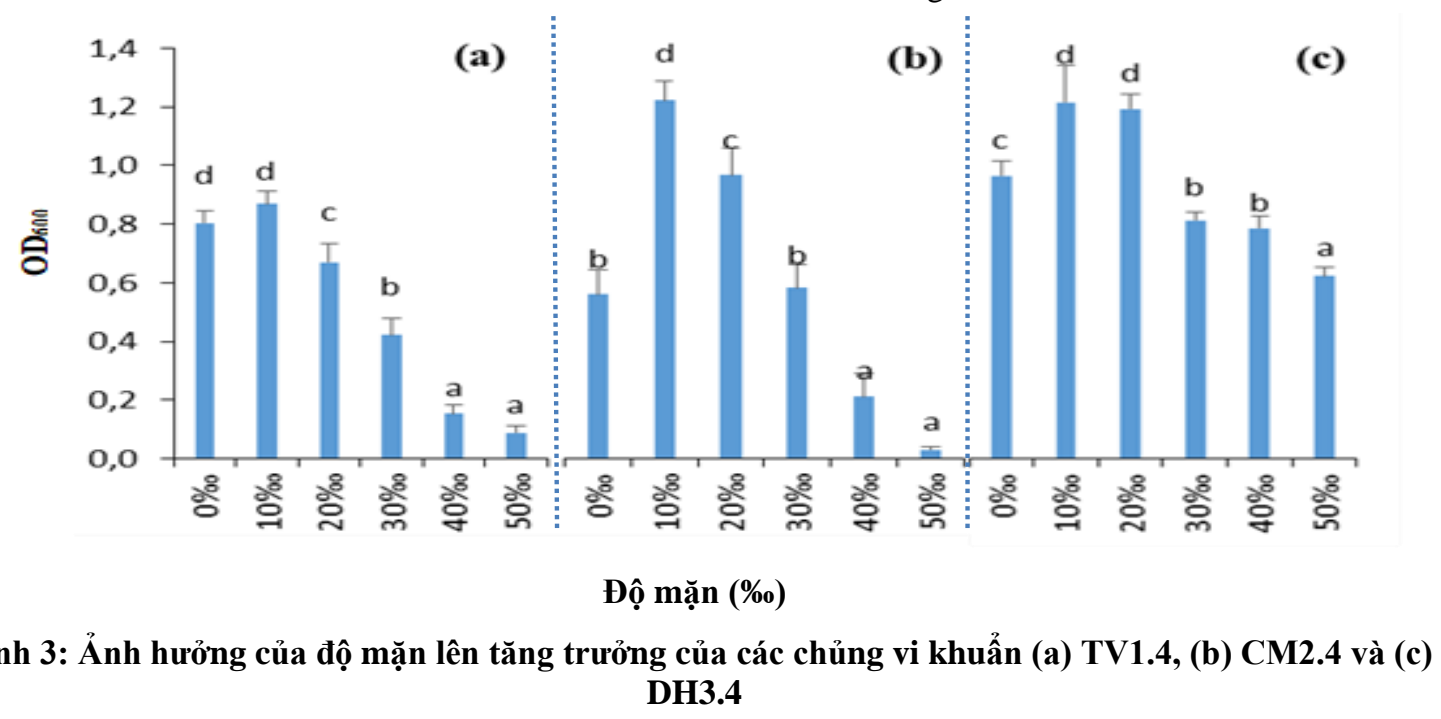

Các giá trị trung bình có các ký tư mũ a, b, c khác nhau thì khác biệt có ý nghĩa thống kê $(p<0,05)$.

\subsubsection{Anh hương của nguồn $C$}

Khả năng đồng hóa các nguồn $\mathrm{C}$ là một trong những chỉ tiêu quan trọng để phân loại xạ khuẩn. Khi tiến hành nuôi xạ khuẩn trong môi trường có bổ sung riêng biệt các nguồn carbon khác nhau (maltose, saccarose, glucose, starch, glycerol), cho thấy cả 3 chủng xạ khuẩn nghiên cứu đều có khả năng đồng hóa tốt, nguồn starch là nguồn $\mathrm{C}$ phù hợp nhất cho cả 3 chủng vi khuẩn Streptomyces khảo sát. Trong đó chủng TV1.4 phát triển đạt giá trị cao nhất sau 24 giờ thu mẫu với giá trị trung bình $\mathrm{OD}_{600}$ $=1,275$ cao hơn và khác biệt có ý nghĩa thống kê $(p<0,05)$ so với các nghiệm thức còn lại (Hình $4 \mathrm{a})$ cũng ở nghiệm thức này chủng CM2.4 cũng có tốc độ tăng trưởng cao nhất với giá trị $\mathrm{OD}_{600}=0,969$ cao hơn và khác biệt có ý nghĩa thống kê $(p<0,05)$ so với các nghiệm thức còn lại (Hình $4 \mathrm{~b}$ ). Tương tự như 2 chủng trên, giá trị $\mathrm{OD}$ của chủng DH3.4 ở nghiệm thức sử dụng starch có tốc độ tăng trưởng cao nhất với giá trị $\mathrm{OD}_{600}=1,060$ và cao hơn có ý nghĩa thống kê $(p<0,05)$ (Hình 4c). 


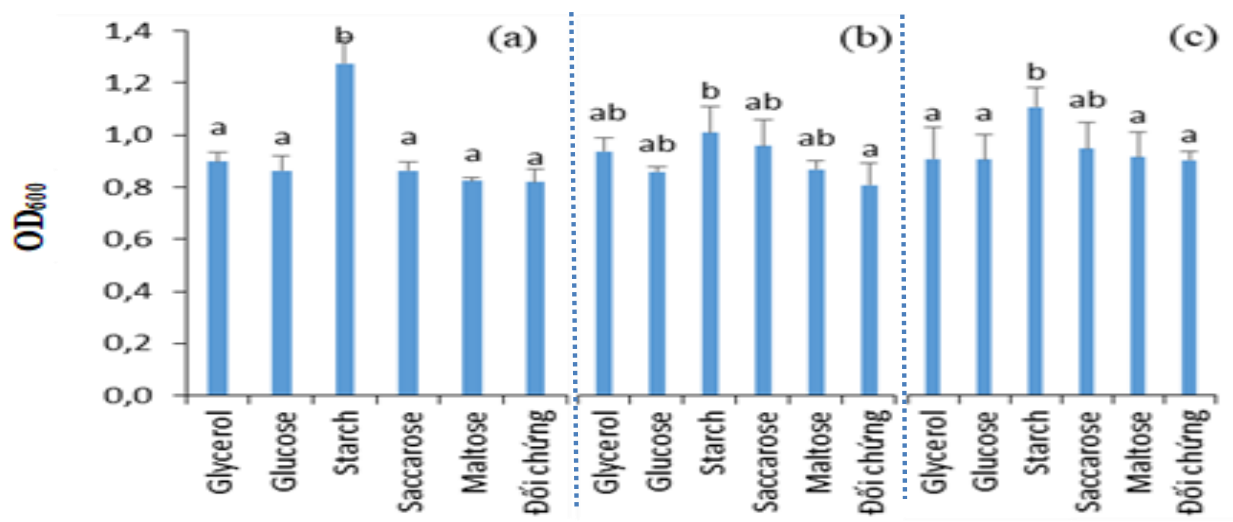

(c)

Hình 4: Ảnh hưởng của nguồn C lên tăng trưởng của các chủng vi khuẩn (a) TV1.4, (b) CM2.4 và (c) DH3.4

Các giá trị trung bình có các ký tụ mũ a, b, c khác nhau thì khác biệt có ý nghĩa thống kê ( $p<0,05)$.

Sau khi xác định được nhiệt độ, pH và độ mặn thích hợp cho từng chủng vi khuẩn, vi khuẩn được nuôi trong điều kiện thích hợp nhất có bổ sung nguồn starch. Kết quả cho thấy đối với chủng TV1.4 ở nồng độ $2 \%$ và $3 \%$ starch mật độ vi khuẩn đạt cao nhất với giá trị $\mathrm{OD}_{600}$ lần lượt là 1,299 đến 1,330 cao hơn và khác biệt có ý nghĩa thống kê so với các nghiệm thức còn lại $(p<0,05)$ (Hình $5 \mathrm{a})$. Đối với chủng CM2.4, nghiệm thức có nồng độ starch $1 \%$ $\left(\mathrm{OD}_{600}=0,902\right)$ có mật độ vi khuẩn cao hơn và khác biệt có ý nghĩa thống kê $(p<0,05)$ so với các nghiệm

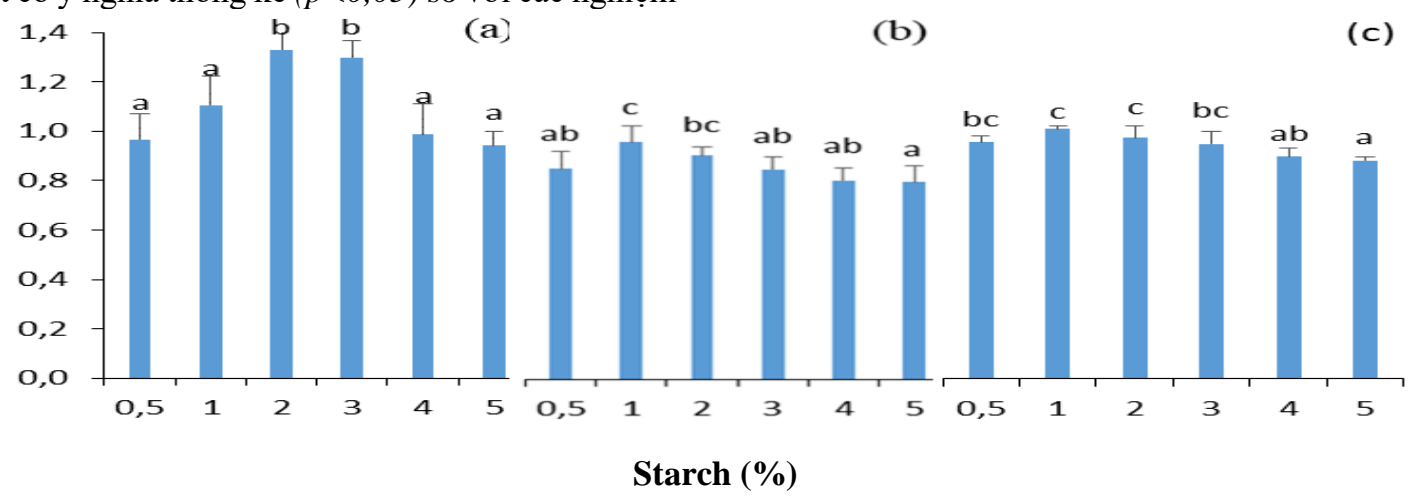

Hình 5: Ảnh hưởng của nồng độ starch lên tăng trưởng của các chủng vi khuẩn (a) TV1.4, (b) CM2.4 và (c) DH3.4

\subsubsection{Anh hưởng của nguồn $N$}

Kết quả khảo sát nguồn $\mathrm{N}$ (potassium nitrate, ammonium sulfate, peptone, tryptone, casein) thích hợp cho thấy, chủng TV1.4 ở nghiệm thức có chứa nguồn nito tryptone có mật độ cao nhất, $\left(\mathrm{OD}_{600}\right.$ $=1,626)$ cao hơn và khác biệt có ý nghĩa thống kê $(p$ $<0,05$ ) so với các nghiệm thức còn lại (Hình 6a). Trong khi đó chủng CM2.4 được có mật độ cao nhất thức còn lại (Hình $5 b$ ). Chủng DH3.4 cũng có mật độ vi khuẩn cao nhất ở nghiệm thức starch $1 \%$ $\left(\mathrm{OD}_{600}=0,952\right)$ khác biệt không có ý nghĩa thống kê so với nghiệm thức $2 \%(p>0,05)$ nhưng lại cao hơn và khác biệt có ý nghĩa thống kê so với các nghiệm thức còn lại (Hình $5 \mathrm{c}$ ). Với kết quả nguồn $\mathrm{C}$ tốt nhất là starch phù hợp với báo cáo của một số nhà nghiên cứu cho rằng, các polysacarit như starch và glycerol thường là nguồn carbon tốt nhất vì chúng hỗ trợ tốc độ tăng trưởng cho vi khuẩn (Jonsbu et al., 2002).

4 nguồn $\mathrm{N}$ bao gồm peptone, caseine, $\mathrm{KNO}_{3}$ và tryptone và khác biệt không có ý nghĩa thống kê. Tuy nhiên peptone là nguồn nguyên liệu được chọn trong thí nghiệm tiếp theo (Hình 6b), do mật độ vi khuẩn khi nuôi bằng peptone cao hơn tryptone. Tương tự như khuynh hướng này chủng $\mathrm{DH} 3.4$ vi khuẩn có mật độ cao nhất $\left(\mathrm{OD}_{600}=1,090\right)$ khi được nuôi bằng peptone (Hình $6 \mathrm{c}$ ). 

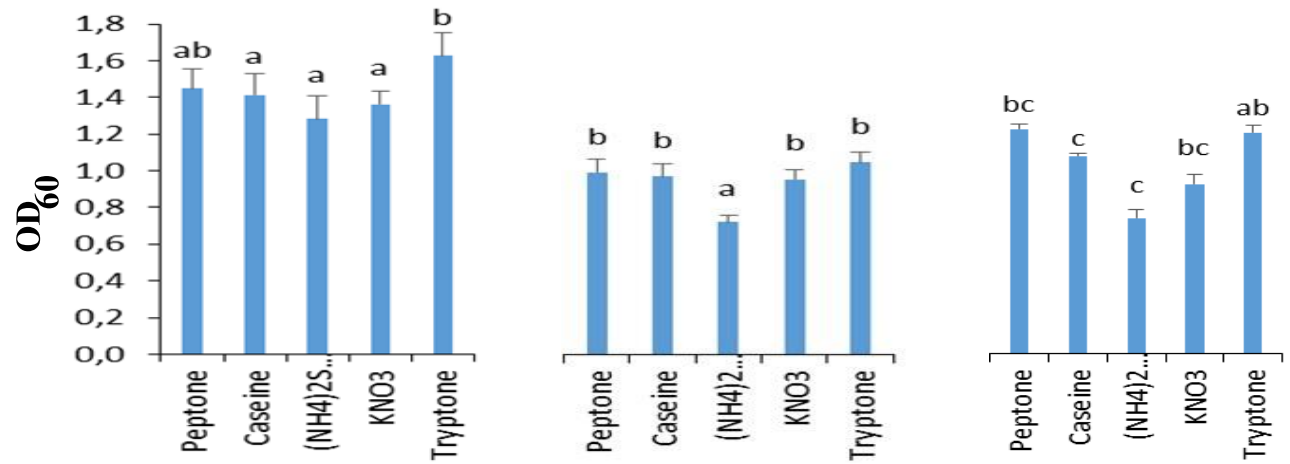

Hình 6: Ảnh hưởng của nguồn $\mathrm{N}$ lên tăng trưởng của các chủng vi khuẩn (a) TV1.4, (b) CM2.4 và (c) DH3.4

Các giá trị trung bình có các ký tụ mũ a, b, c khác nhau thi khác biệt có ý nghĩa thống kê ( $p<0,05)$.

Sau khi đã xác định được nguồn $\mathrm{N}$ thích hợp lên từng chủng vi khuẩn, 3 chủng vi khuẩn được chọn đã nuôi trong nguồn $\mathrm{N}$ phù hợp. Tryptone được chọn là nguồn $\mathrm{N}$ tốt nhất cho sự tăng sinh của chủng TV1.4. Ở nồng độ tryptone $2 \%$ vi khuẩn tăng sinh tốt nhất $\left(\mathrm{OD}_{600}=1,268\right)$ cao hơn và khác biệt có ý nghĩa thống kê $(p<0,05)$ so với các nghiệm thức còn lại (Hình 7a). Đối với chủng CM2.4 peptone được chọn là nguồn $\mathrm{N}$ tốt nhất cho sự tăng sinh của vi khuẩn này. Nghiệm thức có nồng độ peptone $1 \%$ vi khuẩn tăng sinh cao nhất $\left(\mathrm{OD}_{600}=1,194\right)$ cao hơn có ý nghĩa thống kê $(p<0,05)$ so với các nghiệm thức còn lại (Hình $7 b$ ). Tương tự với chủng CM2.4, peptone cũng được chọn là nguồn cung cấp $\mathrm{N}$ tốt nhất cho sự tăng sinh của chủng DH3.4. Ở nghiệm thức có nồng độ peptone $2 \%$ vi khuẩn có tốc độ tăng sinh $\left(\mathrm{OD}_{600}=1,368\right)$ cao hơn có ý nghĩa thống kê $(p<0,05)$ so với các nghiệm thức còn lại (Hình $7 \mathrm{c})$.
Một nghiên cứu cho thấy loại và nồng độ nguồn $\mathrm{N}$ ảnh hưởng rất lớn đến khả năng sinh tổng hợp các hoạt chất của vi khuẩn Streptomyces (Rafieenia, 2013). Tác giả này cho rằng glucose làm giảm khả năng xạ khuẩn tiết ra các chất kháng sinh: oleandomycin, avilamycin, nystatin, spiramycin, neomycin. Trong trường hợp khác nhận thấy glucose làm giảm khả năng tiết enzymes liên quan đến quá trình sinh tổng hợp kháng sinh. Ví dụ, đối với nhóm xạ khuẩn, glucose ảnh hưởng xấu đến tổng hợp phenoxazinone. Nghiên cứu cũng cho thấy môi trường lên men polysaccharides thông thường là nguồn carbon tốt nhất để sản xuất chất kháng sinh. Do vậy chọn lựa nguồn carbohydrates thích hợp sẽ giúp tăng quá trình tăng trưởng của vi khuẩn Streptomyces nhằm thu được tối đa các hoạt tính của vi khuẩn trong nghiên cứu này. Ngoài ra nguồn nitơ đơn giản và vô cơ thường làm tăng tốc độ sinh trưởng của vi khuẩn Streptomyces (Young et al., 1985). (a)

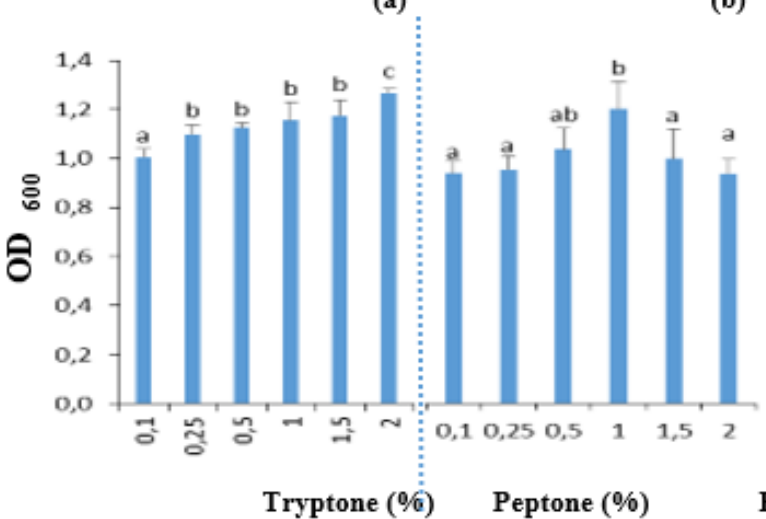

(c)

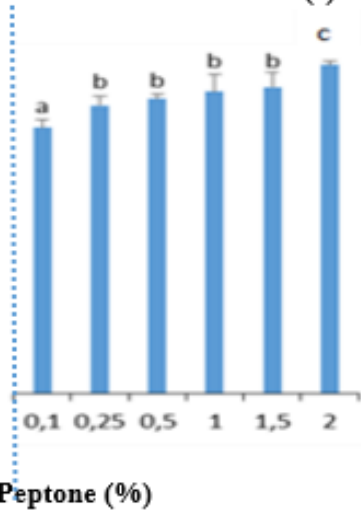

Hình 7: Ảnh hưởng của nguồn $\mathrm{N}$ lên tăng trưởng của các chủng vi khuẩn TV1.4, (b) CM2.4 và (c) DH3.4

Các giá trị trung bình có các ký tụ mũ a, b, c khác nhau thì khác biệt có ý nghĩa thống kê ( $p<0,05)$. 


\section{KẾT LUẬN VÀ ĐỀ XUẤT}

\subsection{Kết luận}

Chủng TV1.4 phát triển tốt nhất ở pH 7, nhiệt độ $30^{\circ} \mathrm{C}$, độ mặn $10 \%$, starch $2 \%$, tryptone $2 \%$. Chủng $\mathrm{CM} 2.4$ phát triển tốt nhất ở $\mathrm{pH} 8$, nhiệt độ $40^{\circ} \mathrm{C}$, độ mặn $10 \%$, starch $1 \%$, tryptone $1 \%$ và chủng $\mathrm{DH} 3.4$ phát triển tốt $\mathrm{pH} 7$, nhiệt độ $35^{\circ} \mathrm{C}$, độ mặn $10 \%$, starch $1 \%$ và tryptone ở nồng độ $2 \%$. Trong 3 chủng nghiên cứu chủng Streptomyces TV1.4 tốt nhất.

\section{2 Đề xuất}

Tiếp tục bố trí các thí nghiệm ở quy mô lớn hơn để đánh giá ảnh hưởng của các tác động môi trường đến khả năng tăng sinh của vi khuẩn.

\section{LỜI CẢM TẠ}

Đề tài này được tài trợ bởi Dự án Nâng cấp Trường Đại học Cần Thơ VN14-P6 bằng nguồn vốn vay ODA từ Chính phủ Nhật Bản.

\section{TÀI LIỆU THAM KHẢO}

Akond, M. A., Jahan, M. N., Sultana, N. and Rahman, F., 2016. Effect of temperature, $\mathrm{pH}$ and $\mathrm{NaCl}$ on the isolates of Actinomycetes from straw and compost samples from Savar, Dhaka, Bangladesh. American Journal of Microbiology and Immunology. 1(2): 10-15.

Balcazar, J.L., T. Rojas-Luna and D.P. Cunningham, 2007. Effect of the addition of four potential probiotic strains on the survival of pacific white shrimp (Litopenaeus vannamei) following immersion challenge with Vibrio parahaemolyticus. Journal of Invertebrate Pathology. 96 (2): 147-150.

Crumlish, M., Dung, T. T., Turnbull, J. F., Ngoc, N. T. N. and Ferguson, H. W., 2002. Identification of Edwardsiella ictaluri from diseased freshwater catfish, Pangasius hypophthalmus (Sauvage), cultured in the Mekong Delta, Vietnam. Journal of Fish Diseases. 25(12): 733-736.

Deeble, V., Fazeli, M., Cove, J., \& Baumberg, S., 2005. Effects of temperature on production of antibiotics in Streptomyces griseus. Journal of antibiotics. 171-178.

James, P., and Edwards, C., 1989. The effects of temperature on growth and production of the antibiotic granaticin by a thermotolerant streptomycete. Journal of General Microbiology. 135: 1997-2003.

Jonsbu, E., McIntyre, M. and Neilson, J., 2002. The influence of carbon sources and morphology on nystatin production by Streptomyces noursei. Journal of Biotechnology. 95(2): 133-144.

Kiranmayi, M. U., Sudhakar, P., Sreenivasulu, K. and Vijayalakshmi, M., 2011. Optimization of culturing conditions for improved production of bioactive metabolites by Pseudonocardia sp. VUK-10. Mycobiology. 39(3): 174-181.

Lee, M., and Demain, A., 1997. Effects of nitrogen source on production of antibiotics Journal of Microbiology. 412-422.

Lightner, D.V., R. M. Redman, C. R. Pantoja, B. L. Noble, Loc Tran, 2012. Early mortality syndrome affects shrimp in Asia. Global Aquaculture Advocate. p:40.

Mohkam, M., Nezafat, N., Berenjian, A., Mobasher, M. A., and Ghasemi, Y., 2016. Identification of Bacillus probiotics isolated from soil Rhizosphere using 16S rRNA, recA, rpoB gene sequencing and RAPD-PCR. Probiotics Antimicrob Proteins. 8(1): 8-18.

Nguyễn Thị Minh Hằng và Đỗ Văn Bút, 2013. Phân lập và tuyển chọn các chủng xạ khuẩn Actinomycetes phân giải cellulose từ đất rừng. Hội nghị khoa học toàn quốc.

Rafieenia, R., 2013. Effect of nutrients and culture conditions on antibiotic synthesis in Streptomycetes. Asian Journal of Pharmaceutical Sciences and Health. 3 (3): 810-821.

Robati, R. and Mathivanan, N., 2013. Antagonistic activity of Streptomyces sp. MML1715 against Rhizoctonia solani, Annals of Biological Research 4 (5): 156-158.

Sanglier, J., Haag, H., Huck, T., \& Fehr, T., 1993. Novel bioactive compounds from Actinomycetes. Research in Microbiology. 144(8): 661-663.

Srivibool, R., Kurakami, K., Sukchotiratanac, M., \& Tokuyamab, S., 2004. Coastal soil actinomycetes: Thermotolerant strains producing $\mathrm{N}$-Acylamino acid racemase. Science Asia (30): 123-126.

Verschuere, L., G. Rombaut, P. Sorgeloos, and W. Verstraete, 2000. Probiotic bacteria as biological control agents in aquaculture. Microbiology Mol. Biol. Rev, 64: 655-671.

Young, M., and Kempe, L., 1985. Effects of phosphate, glucose, and ammonium on cell Growth and lincomycin production by Streptomyces irncohensis in chemically defined media. Biotechnology and Bioengineering. 55(2): 327-333.

Phan Thị Hồng Thảo, Nguyễn Vũ Mai Linh, Nguyễn Thị Hồng Liên, Nguyễn Kiều Băng Tâm, Nguyễn Văn Hiếu, 2016. Xạ khuẩn nội sinh Streptomyces parvulus HNR3X4 trên cây bưởi Diễn Hà Nội và tiềm năng sinh tổng hợp chất kháng khuẩn. Tạp chí Khoa học Đại học quốc gia Hà Nội. Khoa học Tự nhiên và Công nghệ, Tập 32, Số (1S): 327-333. 